Publisher homepage: www.universepg.com, ISSN: 2663-6913 (Online) \& 2663-6905 (Print) https://doi.org/10.34104/ajpab.019.01944048

\title{
Dengue and Recent Mosquito-borne Viral Fever Outbreak in Bangladesh: Concern, Causes and Control
}

\section{Shazeed-Ul-Karim ${ }^{1,2 *}$}

${ }^{1}$ Dept. of Microbiology, Jahangirnagar University, Dhaka-1342, Bangladesh; and ${ }^{2}$ Center for Higher Studies and Research, Bangladesh University of Professionals, Dhaka-1216, Bangladesh.

*Correspondence: shazeed0412@gmail.com

\begin{abstract}
Bangladesh is struggling with dreadful outbreaks of mosquito-borne diseases for past few years. Disease Control Division of Directorate General (DG) of Health Service considered the capital of Bangladesh as breeding ground for mosquitos. Recent incidence of Dengue and Chikungunya outbreaks have surpassed all past records of outbreak. Thus, country is witnessing elevated rate of viral fever incidence alarmingly. Though symptoms of mosquito-borne viral infection are very typical, the recent incidence of fatalities is growing great public health concern. World Health Organization (WHO) recommends practical control measures to minimize the breeding within the community of Bangladesh. The actions of Kolkata City Corporation to control Dengue are also suggestive for Bangladesh. There is no medication to treat Dengue, and Chikungunya infection, but initial recognition and apposite medical care can reduce the death threat.
\end{abstract}

Keywords: Dengue, Chikungunya, Aedes Mosquito, Fever, Incidence and Outbreak.

\section{INTRODUCTION:}

A fever which is occurred as a result of viral infection in a human body known as viral fever. Incidence of mosquito-borne viral fever is very common prevalence in South Asia. Dengue and Chikungunya are endemic in South Asian countries during monsoons as heavy rainfall generates a perfect breeding ground for mosquitos. In recent years Bangladesh is witnessing several viral fever outbreaks, among which mosquito-borne viral fever has become a great public health concern. The alarming number of Dengue and Chikungunya cases has been recorded in the capital, Dhaka as well as nationwide for past few years.

This year (2019) the situation of dengue incidence has become even worse and has broken all the previous records of dengue outbreak. The massive outbreak of Chikungunya virus also happened for the first time in Bangladesh in 2017. Though the symptoms of viral fever are very common, this may turn to threatening complication which often leads to death. Viral illness does not respond to any antibiotic. Moreover, no vaccine and specific medicine are available to the treatment of Dengue, and Chikungunya 
infection. Precaution and appropriate control measures can curtail the risk of seasonal viral fever outbreak in Bangladesh.

\section{Dengue Fever}

Dengue fever is a mosquito-borne viral disease. The infective female Aedes aegypti mosquito is the vector for transmitting dengue virus to human through its bites after acquiring the virus while feeding on the blood of a diseased person (WHO, 2009).

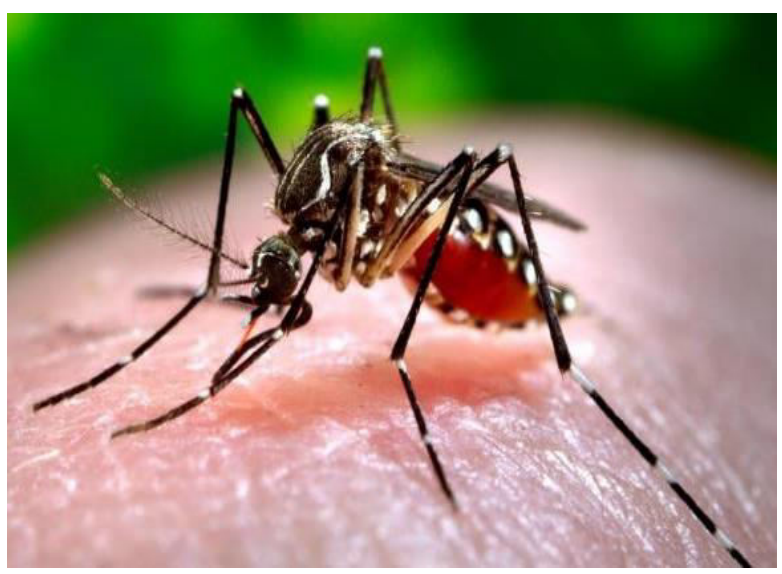

Fig 1: Aedes mosquito (Source: The Daily Star, 2019).

In Bangladesh, the first incidence of dengue infection was identified in 2000. From then on, until 2018; more than half lakh people were suffered from dengue fever and among them nearly 300 people died (The Daily Star, July 10, 2019). The situation has become even worse this year (2019) and has broken all the previous records of dengue outbreak (The Daily Star, July 10, 2019). According to Directorate General of Health Service (DGHS), from beginning of January to third week of July in 2019, more than 6500 people were hospitalized due to dengue cases in various hospitals of Dhaka City (Dhaka Tribune, July 22, 2019). Another study estimated almost 30000 patients who were hospitalized with dengue fever nationwide (Firstpost, August 08, 2019). Surprisingly, July 2019 saw the giant number of dengue incidence in terms of month in the history of
Bangladesh (The Daily Star, August 03, 2019; The Financial Express, July 29, 2019).

According to WHO, the clinical symptoms may vary according to the age. Symptoms typically include high fever with headache, vomiting, nausea, muscle, and joint pains, rash, swollen glands, and pain behind the eyes. Currently, new features like loose motion, renal failure, and pneumonia have identified in Bangladesh (Dhaka Tribune, July 22, 2019). Most importantly, secondary dengue infection sometimes creates hemorrhagic fever which often leads to death (Suzuki et al., 2019).

\section{Chikungunya Fever}

Chikungunya fever is also a mosquito-borne disease of human caused by Chikungunya virus. Like dengue, Aedes aegypti mosquito is also the vector of Chikungunya infection. Another vector of this illness is Aedes albopictus mosquito. These two species usually bite human throughout daylight hours (WHO, 2016). In Bangladesh the first epidemic of Chikungunya fever was identified in Rajshahi and Chapianawabganj districts (Hassan et al., 2014).The major epidemic of Chikungunya virus happened for the first time in the Capital of Bangladesh between May and September in 2017 (Hossain and Hasan, 2018).

The symptoms are as common as dengue fever. Symptoms usually appear 3 to 7 days after infection. The most typical symptoms are fever and joint pain. Other symptoms include headache, rash, muscle pain, joint swelling. Though Chikungunya infection is not as deadly as dengue infection, the symptoms can be severe to disabling (CDC, 2019).The most alarming is that fetus and newborn can be infected after maternal Chikungunya infection during gestation (Despina and Shoshana, 2018) 


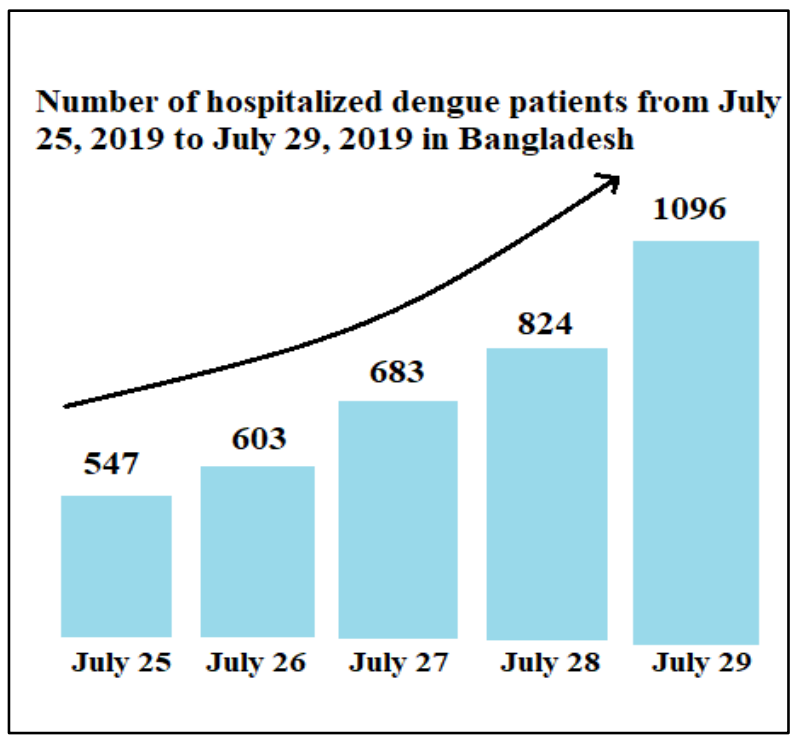

Fig 2: Ascending incidence of dengue infection between 25 and 29 July, 2019 (The Financial Express, July 29, 2019).

\section{Causes}

The causes of dengue and Chikungunya breeding are similar. An investigation led by the Disease Control Division of DGHS, exposed that densely populated Dhaka is now considered as preferred breeding ground for Aedes mosquitos. The possible breeding grounds for the carrier (mosquito) are places with stagnant water, flower tubs, discarded cup and mug, clay and paint pots, plastic or metal pack, discarded tires, uncovered water tanks and stagnant rainy water (Dhaka Tribune, July 22, 2019).

\section{Control and Cure}

To control dengue fever and Chikungunya fever, the first obligatory step is to control the breeding of Aedes mosquitos. WHO recommends few practical control measures to minimize the breeding within the community of Bangladesh which include -

a) Proper storage, collection and disposal of solid waste.

b) Cleaning of street, drainage and removing water bearing containers.

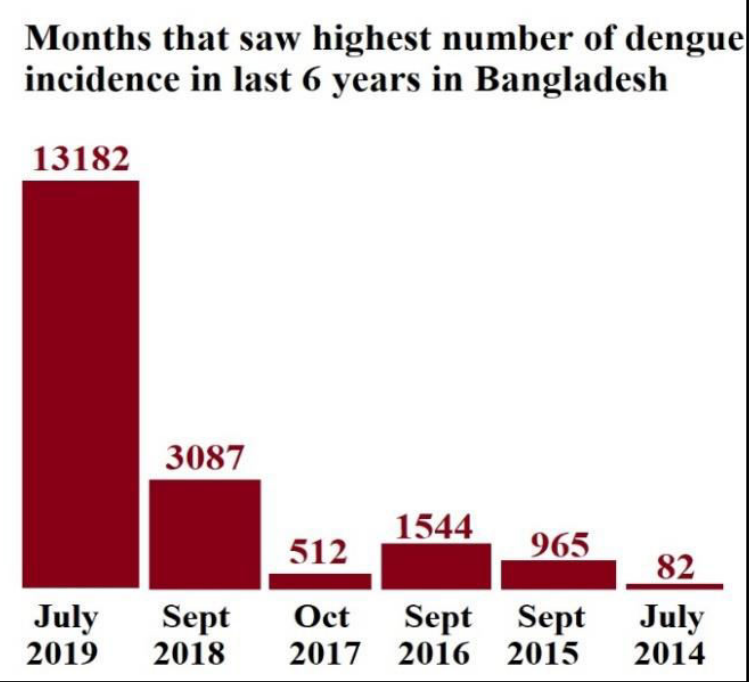

Fig 3: July 2019 saw the highest incidence of Dengue in the history of Bangladesh (The Daily Star, August 03, 2019).

c) Destroying/altering/removing/recycling of non-essential containers.

d) Well-maintaining of water-storage containers.

e) Hanging mosquito net over sleeping bed as well as installing on the every entrance of the house, and

f) Clothing which reduce skin contact to the day-biting mosquitos.

The successful actions of Kolkata City Corporation to control Dengue are also the exemplars for Bangladesh to control dengue, and Chikungunya incidence. Those successful approaches were -

a) Arranging awareness campaign on the diseases.

b) Keeping Rapid Action Teams standby for destroying mosquito breeding.

c) Monitoring, and

d) Diagnosing infection and providing treatment (The Daily Star, Aug 01, 2019)

Dengue infection can be deadly if it creates hemorrhagic fever and Chikungunya fever often may be severe to adult and newborn. 
According to $\mathrm{WHO}$, there is no vaccine or medicine available to treat dengue, and Chikungunya infection. Treatment is focused primarily on relieving the sign and symptoms. Infected patient should take proper rest, drink plenty of fluids, sponge the body with water, get doctor for painkilling medication, and get tested for fever and pain.

\section{Other mosquito-borne Viral Fever}

Bangladesh has a past incidence of Zika virus infection. The vectors of this viral transmission are as similar as Chikungunya fever, Aedes aegyptiand Aedes albopictus mosquitos. Currently, in Bangladesh there is no evidence of ongoing Zika Virus epidemic (IAAMT, 2019).

Another mosquito borne viral fever is Yellow Fever. The causative vector of this infection is Aedes aegypti. This infection is not frequent like dengue or Chikungunya. Most of the infected persons are asymptomatic or have mild symptoms with complete return to healthy state (The Daily Star, July 30, 2017)

\section{CONCLUSION:}

Though different mosquito-borne viral fevers are very common in Bangladesh, the recent outbreaks with numerous fatalities are raising great concern to the public health. However, in case of any viral fever, people should not be panicked over symptoms. Infected or suspected patient should take proper rest, drink lots of fluid, and if pain and fever linger, one must visit doctor, take painkillers on doctor's advice and undergo diagnostic tests. Current outbreak is also the lesson for the City Corporation, Ministry of Health and Diseases Control Division as well as all concern officials to take preparatory actions to avoid future outbreak.

\section{ACKNOWLEDGEMENT:}

The author is thankful to his colleagues of Bangladesh University of Professionals (BUP) who encouraged and supported to write this review.

\section{CONFLICT OF INTEREST:}

The author declares that there is no conflict of interest about the publication of the article.

\section{REFERENCES:}

1. World Health Organization, (2009). http://www.searo.who.int/bangladesh/de ngue/en/

2. The Daily Star, July 10, (2019). https://www.thedailystar.net/frontpage/de ngue-fever-in-dhaka-cause-for-alarmnow-1769179

3. Dhaka Tribune, July 22, (2019). https://www.dhakatribune.com/banglades h/2019/07/22/is-dengue-turning-into-anepidemic

4. Firstpost, August 08, (2019). https://www.firstpost.com/world/dengueoutbreak-in-bangladesh-we-are-scaredsay-residents-as-viral-fever-overwhelmsnation-23-dead-so-far-7133191.html

5. The Daily Star, August 03, (2019). https://www.thedailystar.net/country/den gue-fever-outbreak-1649-hospitalised-in24-hours-1781182

6. The Financial Express, July 29, (2019). https://thefinancialexpress.com.bd/nation al/dengue-spreads-to-50-districts1564408195

7. Suzuki K., Nakayama E., Satio A., (2019). Evalution of novel rapid detection kits for dengue virus NS1 antigen in Dhaka, Bangladesh, in 2017. Virology journal; 16: 102.

8. World Health Organization, (2016). http://www.searo.who.int/bangladesh/aed escontrol/en/

9. Hassan R, Rahman M, Moniruzzaman M, (2014). Chikungunya- an emerging 
infection in Bangladesh: a case series. Journal of Medical Case Reports; 8: 67.

10. Hossain M S, and Hasan M M, (2018). Chikungunya Outbreak (2017) in Bangladesh: Clinical profile, economic impact and quality of life during the acute phase of the diseases. Plos Neglected Tropical Diseases; 12: 6.

11. Centers for Disease Control and Prevention (CDC), (2019).

https://www.cdc.gov/chikungunya/sympt oms/index.html

12. Despina C, and Shoshana N, (2018). Mother-to-child transmission of Chikun- gunya Virus: A systematic review and meta-analysis. Plos Neglected Tropical Diseases; 12: 6.

13. The Daily Star, Aug 01, (2019). https://www.thedailystar.net/frontpage/k olkata-shows-the-way-to-control-denguein-india-1780021

14. International Association for Medical Assistance to Travelers (IAAMT), (2019). Bangladesh General Health Risk: Zika Virus.

15. The Daily Star, July 30, (2017). https://www.thedailystar.net/health/healt h-tips/how-avoid-yellow-fever-1440709

Citation: Shazeed-Ul-Karim, (2019). Dengue and recent mosquito-borne viral fever outbreak in Bangladesh: concern, causes and control, Am. J. Pure Appl. Sci., 1(6), 44-48. https://doi.org/10.34104/ajpab.019.01944048 